\title{
An Analysis of Non-Formal Curricular Activities in Mumias Sub-County, Kenya
}

\author{
Abisaki Oloo \\ abisakiaono@yahoo.com \\ Kibabii University College
}

\author{
Dr. S.N Mutsotso \\ smutsotso@kibabiiuniversity.ac.ke \\ Kibabii University College
}

\author{
Dr Moses Poipoi \\ wesangulamp@yahoo.com \\ Masinde Muliro University \\ of Science and Technology
}

DOI: $\quad 10.6007 /$ IJARBSS/v3-i9/248 URL: http://dx.doi.org/10.6007/IJARBSS/v3-i9/248

\begin{abstract}
The presence of non-formal curricular activities in schools and the availability of resources that promote the same are indicators of possible implementation of NFCAS. Hence the focus of this study was to analyze the NFCAS offered in secondary schools in Mumias Sub-County, Kakamega County. In order to achieve the set objectives the researcher sought to establish the NFCAS that are available in secondary schools and the NFCAS that were popular, the adequacy of the facilities that promote NFCAS and the frequency of participation of students in NFCAS. Descriptive survey design was employed. Random sampling was undertaken to identify the school types while purposive sampling was used to select the respondents that were information rich. 16 schools, 22 heads of schools, 154 teachers, 1154 students and 1 District Quality Assurance and Standards Officer were derived from the total population. The NFCAs available included a variety of games and sports, clubs and societies and performing arts; Football, Netball and Volleyball were most popular games whereas basketball was the least popular The study concluded that student's access to and participation in non-formal curriculum activities is limited due to lack of adequate facilities and unavailability of time. Recommendations of the study were that the scope of the activities be broadened to involve whole school populations and that schools strengthen their support of the activities. In conclusion the Ministry should ensure that guidelines on registration of schools based on availability of space be adhered to.
\end{abstract}

Key words: Analysis, non-formal curricular activities, secondary schools

\section{Introduction}

A school curriculum has three dimensions, the formal, non-formal and informal which are prerequisites for a holistic approach towards learning and in turn well balanced development of learners (Oluoch, 1994). Today, in, Kenya curriculum implementers appear to negate this proposition. They do this through over emphasizing the formal aspect of the curriculum alone. There is therefore a great obsession in endevouring to achieve high mean scores to earn schools names achieved through high placing in the national ranking of schools. They argue that good grades will enable the child eligibility to institutions of higher learning and in turn better chances into the world of employment. The consequence of promoting formal curriculum is the exclusion of non-formal curriculum activities in schools. Either the activities are partially 
incorporated in the curriculum offered by schools or discarded altogether because the nonformal curriculum activities are 'hindrances' to schools in their quest for high 'mean scores'. It is no wonder that the activities are erroneously referred to as co-curricular or extracurricular activities because the assumption is that they are not core curriculum. The current situation is that of formal curriculum failing to guarantee direct employment. Yet, the other side of the coin presents individuals who are in employment through developing their talents which promotion of NFAS vouches for.

To fully understand curriculum we can borrow from Dewey's "experience and education" as well as Caswell and Campbells "experiences children have under the guidance of the school" (Ornstein, 1988). Aptly put curriculum is broad. It encompasses all the activities that learners to undertake in school; the formal, informal and the non-formal aspect. The latter was a concern for this study given that the non-formal dimension has been relegated and considered 'a waste of learning time' with teachers being reluctant to allow students participate in the non-formal curriculum activities.

The general aims and objectives of education gear towards developing all-round well balanced individuals who foster personal, natural, international, social, economic and cultural development. One of the goals of education is to foster nationalism, patriotism and promote national unity. Another is to promote social, economic, technological and industrial needs for national development (KIE, 2002). These and other goals of education cannot be achieved wholesomely if individuals do not strive to make their contribution towards these goals; education therefore provides opportunities for the fullest development of individual's talents and personality. It helps children develop their potential interests and abilities. Emphasis needs to be placed on practical, holistic education that should cater for every aspect of life to enable an individual adjust well to the fast changing environment.

Gachathi (1976) observed that examinations tend to exercise undue influence on the education system. They serve the highly selective objectives and content of the formal education system (ROK, 1976). The onetime U.S President John Kennedy in the $20^{\text {th }}$ Century observed that people do not have equal talents. Eshiwani, (1993) noted that Kenya like many other third world countries has been accused of suffering from a certificate syndrome which is a result of an adopted examination system whereby one paper certificate fails to secure an individual a vacancy in the next level. The importance given to certification has precipitated a number of malpractices which can be deemed unethical. The malpractices employed include buying 'exam manuals and compelling teachers to take students through them - class hours becoming cramming sessions with little or non learning (EI team, 1999). (Keller, 1980), observes that it is evident that fulfilling the goals of education and particularly producing competent individuals, needs a serious commitment by schools to use all types of experiences which will hardly be confined to the classroom alone. Schools fail when they take a partial view of education by allowing the core curriculum to crowd out interactive NFCAS from their calendar (Shehu, 2001).

The education system in Kenya places high expectation on academic performance aimed at getting white collar jobs. Secondary schools are evaluated by the public on how many students 
qualify for admission to the public universities, while primary schools are judged on how many are eligible into the highly valued government funded secondary schools. Teachers and students are pressurized to attain high grades and those that perform below parental and government expectations are judged harshly. Wastage in the Kenya Education system is a major concern at all levels. The 2005-2007 secondary school cohorts for example recorded enrolment rated at 146,648 boys and 127,057 girls. The completion rate was 137,300 boys and 113,899 girls respectively (ROK, 2008). The major question then is how do the learners who drop out in schools along the way get absorbed so that they too become 'useful' members of the society? Emerging issues in education highlight the importance of NFCAS through recognition that not all learners have the same learning abilities and talents.

It is against this background that UNICEF in conjunction with the Ministry of Youth and Sports developed talent Academy on realization that the dominant age group is 15-29 years, most of whom have no jobs, are angry and vulnerable to delinquent behavior and violence as evident in 2007 post election violence. Coupled with this, is the fact that the education system has a high wastage rate that sees only 500,000 school leavers enter the saturated job market every year at different levels. Yet employment opportunities in the formal sector remain scarce and pegged onto academic qualifications while the informal sector offers a wide variety of untapped opportunities for the youths who are endowed with talents, emotiveness and creativity. Talent academy recruits purely on merit those children who have talent in music and dance, sports and games. It has one National Youth Talent Academy and satellite talent academies. Schools offer fundamental ground in identifying the talents and the academies nurture these talents to a successful conclusion. (Youth Situation Affairs Analysis Report, 2009).

Presence of NFCAS activities in secondary schools then is an important ingredient for both holistic approaches to learning and ingredients that feed themselves into Talent Academies. Today, Kenya boasts of achievers in areas of Non-formal curricular activities namely; dance and performing Arts, games and sports, notable among them Eric Wainaina (music).

David Lekuta Rudisha (34 years old) Olympic and World Record Champion in 800 meters race, Ezekiel Kemboi (30 years old) to highlight just a few. The three dimensions of the curriculum are therefore equally important for a holistic approach towards learning and in turn full development of learners. The problem of over-emphasis on the formal curriculum alone as it is a means of getting into formal employment jeopardizes the promotion of the non-formal dimension of the curriculum. It is against this background that the study determines the situation of the non-formal curricular activities in Mumias Sub-County.

\section{Methodology}

The study was undertaken in selected schools in Mumias Sub-County in Kenya. It adopted a descriptive survey design in collecting relevant data. The target population was the 10 heads of school, 22 heads of departments in charge of Non-formal curricular activities, 54 teachers, 1159 students and 1 Quality Assurance and Standards Officer.

Interviews, observations and questionnaires were used. Secondary data which included observations and checklists were also instrumental in verifying information from the 
questionnaires. The data was analyzed qualitatively. It was first coded and organized into categories, themes and then analyzed using SPPS. Analyzed data was presented in forms of tables, pie charts and bar graphs.

\section{Results and Discussion}

Table 1: Participation in NFCAs

\begin{tabular}{|l|l|l|l|l|}
\hline & \multicolumn{2}{|c|}{ Teacher } & \multicolumn{2}{c|}{ Students } \\
\hline & Yes \% & No $\%$ & Yes \% & No \% \\
\hline Rugby & 37 & 63 & 23 & 77 \\
\hline Football & 97 & 3 & 96 & 4 \\
\hline Netball & 85 & 15 & 90 & 10 \\
\hline Basketball & 32 & 68 & 35 & 65 \\
\hline Handball & 37 & 63 & 35 & 65 \\
\hline Volleyball & 96 & 4 & 96 & 10 \\
\hline Athletics & 96 & 4 & 96 & 10 \\
\hline Christian Union & 51 & 49 & 92 & 8 \\
\hline Islamic & 56 & 44 & 61 & 39 \\
\hline Science Congress & 87 & 13 & 88 & 12 \\
\hline Debate & 57 & 43 & 86 & 14 \\
\hline Kiswahili & 82 & 18 & 84 & 16 \\
\hline Geography & 71 & 29 & 87 & 13 \\
\hline Music & 86 & 14 & 60 & 40 \\
\hline Drama & 76 & 24 & 65 & 35 \\
\hline
\end{tabular}

In response to the questions on availability of Non-formal curriculum activities, the respondents all seemed to agree that schools offered at least one or all the activities offered in the list of activities provided by the researcher. The range included clubs (both subject based and non subject based), societies in particular (Christian Union, Islamic Religion Union and Young Christian Association) and games and sports and performing Arts, Drama and Music. Though the activities were available, they were unable to fully cater for large school populations. The reasons for this were the rapidly increasing school populations as a result of Free Primary Education (2002) and Free Secondary Education (2008). The large populations have strained the learning resources. Formal learning and non-formal learning have been greatly interfered with more so because the facilities are not expanded in tandem with increased populations. Limited facilities negatively impact on the implementation of NFCAS. 


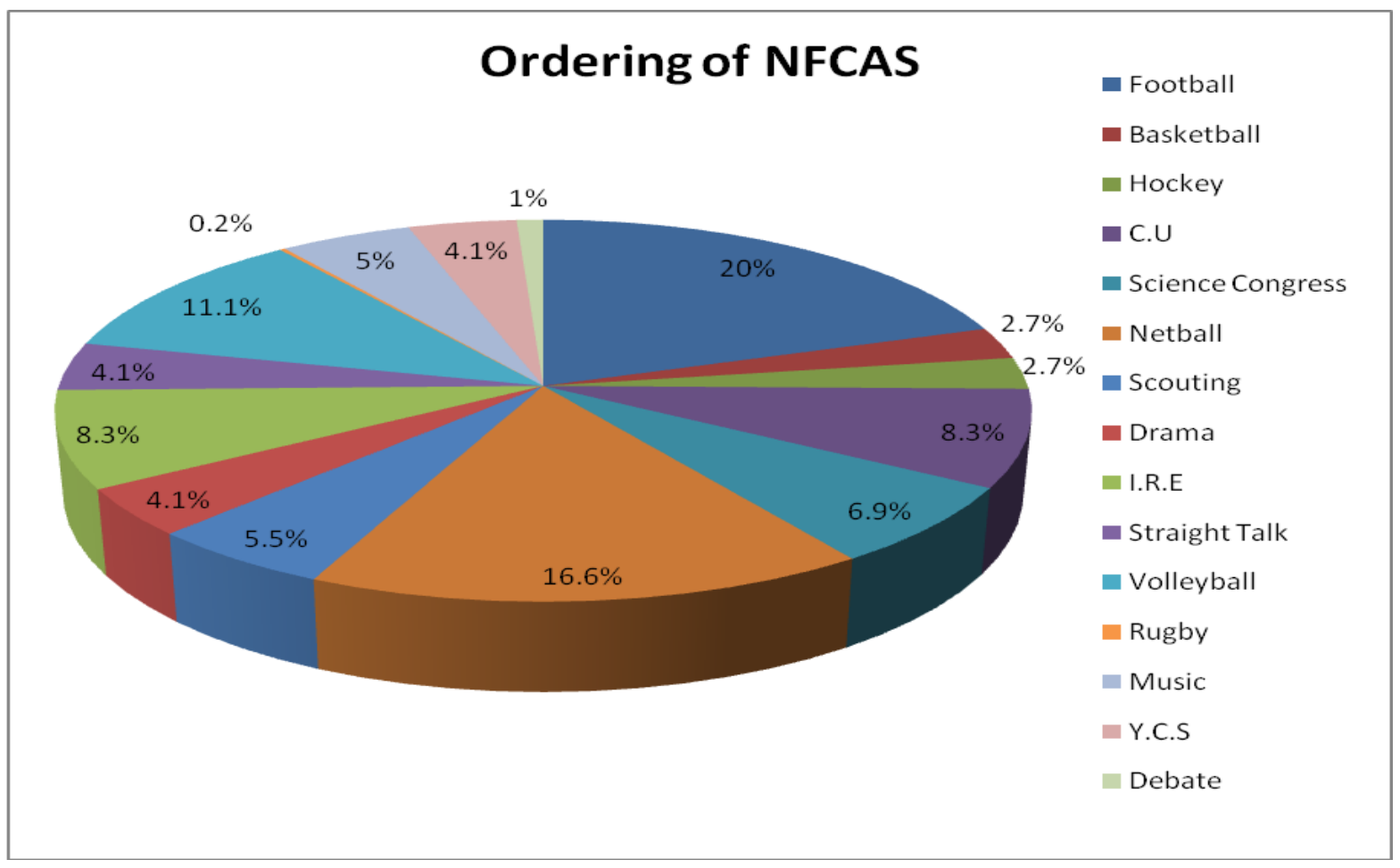

Fig. 1: Ordering Non Formal Curricular Activities Ordering of NFCAS in terms of popularity

Asked to arrange the NFCAS in order of popularity from the most popular to the least popular, the following ranking was achieved. Football, netball and volleyball were considered the most popular. The least popular game was basketball. The rationale behind the popularity of the games was the availability of the activity in the school, the ease of learning/mastery of the activity and the support given by the school (moral and financial).

Lack of popularity on the other hand was realized when the activity lacked adequate facilities to promote it the school performed dismally in the activity or when the activity failed to get the required support from the school administration. Societies have religious affiliations Christian Union and Islamic Religious Union. It had similar ratings in popularity. Young Christian Association followed closely. Clubs were available in all schools. The most popular was Science Congress, followed by straight talk. Debate was the least in popularity. Music was well liked compared to drama. Many schools embraced it and participated in music, competitions. They argued that it allowed participation in the various classes provided for Drama was a present in just a few schools. Many Heads of schools did not promote drama activities because they had negative attitudes towards the same. Generally, they felt that it was expensive for the school and that it led to indiscipline. 


\section{Table 1: $\quad$ Frequency of student participation in NFCAS}

\begin{tabular}{lccc}
\hline & $\begin{array}{l}\text { How often do you } \\
\text { participate in games } \\
\text { and sports? \% }\end{array}$ & $\begin{array}{c}\text { How often do you } \\
\text { participate in clubs } \\
\text { and societies? \% }\end{array}$ & $\begin{array}{c}\text { How often do you } \\
\text { participate in } \\
\text { performing arts? \% }\end{array}$ \\
\hline Never & 6.4 & 5.9 & 43.2 \\
Once in a month & 7.1 & 2.5 & 13.7 \\
Once a fortnight & 3.7 & 2.9 & 5.8 \\
Once a week & 34.1 & 76.9 & 21.8 \\
Daily & 48.6 & 11.8 & 15.5 \\
& $\mathbf{1 0 0 \%}$ & $\mathbf{1 0 0 \%}$ & $\mathbf{1 0 0 \%}$
\end{tabular}

Active participation in non-formal curriculum activities was achieved when there were impending competitions which were guided by the activities calendar provided by the Ministry of Education. Term I promotes ball games, rugby, swimming, basketball, athletics, drama, Science Congress and Scouting on the other hand .Term II A activities include Heptathlon and Decathlon, cross country and hockey. Term II B: soccer, volleyball and racquet games. Students undergo different levels of competition: district, county and regional. Whole school participation would not be achieved in many schools owing to inadequacy of facilities to cater for whole school populations and laxity in supervision by Heads of Department concerned with the activities. Again, in many schools; the time allocated for NFCAS was misappropriated by giving preference to academic activities. There was the school official schedule which incorporated NFCAS. Another timetable which was purely academic leaving no room for the activities was placed alongside it. In some schools this timetable affected only Form 3 and Form 4 but in other schools it was adopted by the whole school. There were many students who recorded having gone through school without getting actively involved in Non-formal curricular activities. In such situations the school administration had failed to strongly supervise the activities.

\section{Adequacy of facilities}

Facilities are key in promoting the activities. Hence the question of adequacy of faciligties that promote NFCAs was investigated. The figure below was derived. 


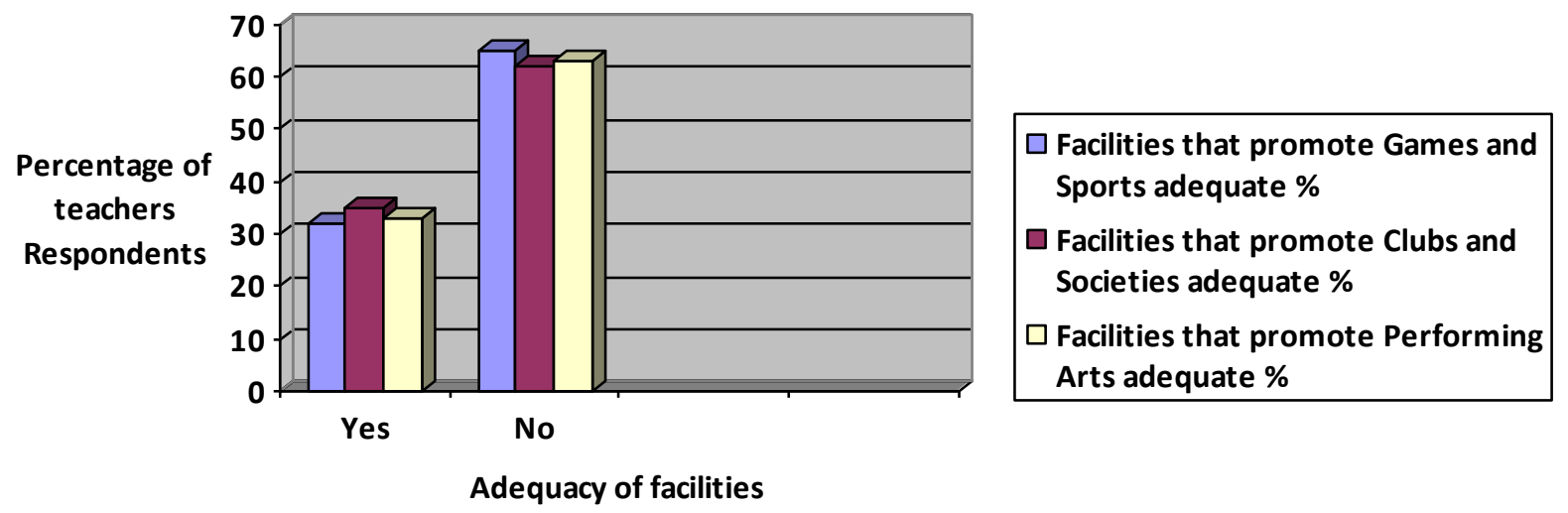

Fig.2: Student responses

The student percentages for inadequacies recorded were $73 \%, 62 \%$ and $66 \%$ in games and sports, clubs and societies and performing arts respectively.

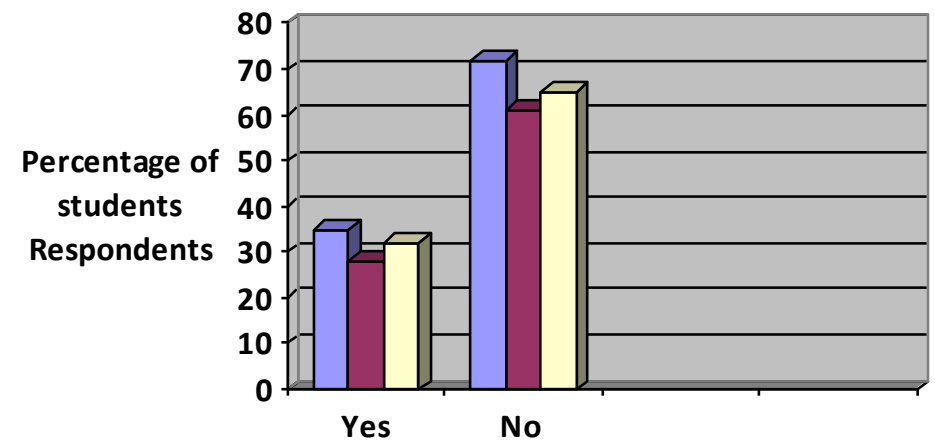

$\square$ Facilities that promote Games and Sports adequate \%

$\square$ Facilities that promote Clubs and Societies adequate \%

$\square$ Facilities that promote Performing Arts adequate \%

\section{Fig.3:Teacher Responses}

Adequacy of facilities

The research investigated whether the facilities that promote NFCAS were adequate. Both the teacher and student respondents agreed that they were inadequacies. Those for teachers in the same areas were 66\%,64\% and 34\% respectively as shown in figure 2 .

Through observation and checklists inadequacy was realized in all the three areas of categorization. Even the most essential facility which is space lacked in many secondary schools especially the upcoming ones. This therefore meant that there was no playing ground. Few secondary schools made effort to share with the neighbouring primary schools, the football and netball pitches. Inadequacies were also in areas of balls, track and field equipment; the discus, shot put, high jump, uniforms and boots. Lack of facilities adversely affected schools participation and directly dictated the school population that was involved in NFCAS at any given time as presented in the table on approximate percentage of participation. 
Table 3: Total school percentage involved in NFCAS

\begin{tabular}{lccccc}
\hline Total Participation & $\mathbf{0 - 1 9 \%}$ & $\mathbf{2 0 - 3 9 \%}$ & $\mathbf{4 0 - 5 9 \%}$ & $\mathbf{6 0 - 7 9 \%}$ & $\mathbf{8 0 - 1 0 0 \%}$ \\
\hline $\begin{array}{l}\text { Total \% of school } \\
\text { population participating } \\
\text { in Games and Sports }\end{array}$ & 13 & 30 & 25 & 21 & 11 \\
$\begin{array}{l}\text { Total \% of school } \\
\text { population participating } \\
\text { in Clubs and Societies }\end{array}$ & 13 & 13 & 17 & 22 & 34 \\
$\begin{array}{l}\text { Total \% of school } \\
\text { population participating } \\
\text { in Performing Arts }\end{array}$ & 42 & 36 & 12 & 5 & 5 \\
\hline
\end{tabular}

The findings in Table 3 do not differ from findings of other researchers. (Humana and Hidaya, 2007) agree that some parents and teachers do not allow their children (students) to be involved in the activities as they too are too preoccupied with academic achievement. The Ministry of Education allocation did not include funds for sports management. Furthermore, there was lack of clear incentives and penalties and the matriculation did not require merit in the activities but it did in academic programmes. Rehema (2010) indicated that schools lack physical, financial and human resources to facilitate participation in NFCAS and where facilities were available they were not efficiency used. Ismat (2009) observed that part of public schools do not hold appropriate infrastructure especially sports ground and this problem was at its worse in private than in public schools. Ismat further observed that there was little time reserved for sports and other non-formal curricular activities in public schools.

\section{Conclusion}

The study made the following conclusions; students' access to and participation in NFCAS in Mumias Sub-county is limited having been influenced by lack of variety of NFCAS and limited facilities. Popularity of activities was concentrated in the area of games and sports. The most popular games were football, netball and volleyball. Facilities were lacking in schools. Funding by the Ministry was inadequate thus negatively affecting procurement of essential equipment such as balls and uniforms. Therefore the study recommends that the school management should broaden the scope of NFCAS in schools to widen participation of students in the activities. The Ministry of Education should develop clear guidelines and policy registration of school based on availability of space and other facilities that promote NFCAS and the Government of Kenya should increase funding allocated to schools to allow procurement of equipment relevant to implementation of NFCAS.

\section{References}

Aggarwal J. C (1982) Theory and Principles of Education (2 ${ }^{\text {nd }}$ Ed.) Delhi Vikas Publishing House. Publication

American Psychological Association (APA, 1994). Manual of the American 
Psychological Association. Washington D.C - APA

Ayudo, H (2009, June 3) Education Outside the Class. The Standard. P27 March 15 (2009).

Bennaars, G.A. J.E Otiende \& Boisvert R. (1994). Theory and Practices of Education, Nairobi: East African Education Publishers Ltd.

Best, J. W \& Kahu J. V (2002) Research in Education ( $8^{\text {th }}$ Ed) New Delhi: Private Ltd.

Bishop G. (1995) Curriculum Development. A Text Book for Students, Hong Kong: Macmillan Education Ltd.

Eshiwani G. S. (1993). Education in Kenya since Independence. Nairobi, E. African Education Publishers.

Ministry of Education (1994). Information Handbook for Teachers, Nairobi: Government Printers.

Ornstein A.\& Hunkins F. (1988) Curriculum: Foundations Principles and Issues Tokyo; Alyn and Bacon.

Oluoch G.P (2002). Essentials of Curriculum Development. Bondo. Bookshop Limited, Nairobi.

Rehema J. (2010) Students Access to Participation in Extra-curricular Activities in Secondary Schools in Tanzania. The case for Dodoma Municipality unpublished M.A dissertation; University of Dar-Es Salaam

Shiundu J. O. \& Omulando S. J (1992). Curriculum Theory and Practice in Kenya. Nairobi, Oxford University Press. 